\title{
PENENTUAN BILANGAN IODIN ADSORBEN KULIT JENGKOL DAN APLIKASINYA DALAM PENYERAPAN LOGAM Pb (II) PADA LIMBAH CAIR INDUSTRI PELAPISAN LOGAM
}

\author{
DETERMINATION OF IODINE NUMBER OF NGAPI NUT PEEL \\ ADSORBENT AND ITS APPLICATION IN THE ADSORPTION OF Pb (II) \\ FROM ELECTROPLATING INDUSTRY WASTEWATER
}

\author{
Setiaty Pandia, Randi Sitorus* \\ Departemen Teknik Kimia, Fakultas Teknik, Universitas Sumatera Utara, \\ Jl. Almamater Kampus USU Medan, 20155, Indonesia \\ *Email : randisitorus@students.usu.ac.id
}

\begin{abstract}
Abstrak
Penelitian ini bertujuan untuk mengetahui pengaruh proses aktivasi terhadap bilangan iodin adsorben serta mengetahui massa adsorben yang optimum dalam menurunkan kadar logam $\mathrm{Pb}$ (II) dalam limbah cair industri pelapisan logam. Kulit jengkol dibersihkan dan dihaluskan dengan ayakan berukuran 100 mesh, kemudian diaktivasi menggunakan asam nitrat $\left(\mathrm{HNO}_{3}\right) 4 \mathrm{~N}$ dengan variasi rasio kulit jengkol : asam nitrat, sambil dipanaskan dengan variasi suhu aktivasi dan lama aktivasi. Kemudian adsorben dikeringkan di oven dengan variasi suhu pengeringan dan lama pengeringan. Proses adsorpsi menggunakan adsorben dengan bilangan iodin tertinggi dan dilakukan dengan variasi massa adsorben tertentu dalam $50 \mathrm{~mL}$ limbah cair. Hasil penelitian memperlihatkan bahwa rasio kulit jengkol : asam nitrat yang optimum adalah $20: 1 \mathrm{mg} / \mathrm{mL}$ pada suhu aktivasi $90{ }^{\circ} \mathrm{C}$, lama aktivasi 120 menit, suhu pengeringan $110^{\circ} \mathrm{C}$ dan lama pengeringan 120 menit dengan bilangan iodin sebesar $634,50 \mathrm{mg} / \mathrm{g}$. Massa adsorben yang optimum adalah $1 \mathrm{~g}$ dengan persen penyerapan logam $\mathrm{Pb}$ (II) sebesar $69,19 \%$.
\end{abstract}

Kata Kunci : adsorben, kulit jengkol, limbah cair, timbal, bilangan iodin

\begin{abstract}
The aim of this research is to study the effect of activation processes to iodine number of ngapi nut peel adsorbent and to study the optimum adsorbent mass to reduce metallic lead $(\mathrm{Pb})$ concentration in electroplating wastewater. Ngapi nut peel was cleaned and mashed to a size of 100 mesh of sieve tray and then activated using nitric acid $\left(\mathrm{HNO}_{3}\right) 4 \mathrm{~N}$ with specific ratio ngapi nut peel : nitric acid while heated at specific activation temperature and duration. Adsorbent dried in oven at specific temperature and duration of drying. Adsorbent with optimum iodine number then used in batch adsorption that carried out by using variations of mass in $50 \mathrm{~mL}$ of wastewater. The results showed that the optimum ratio of ngapi nut peel : nitric acid is $20: 1 \mathrm{mg} / \mathrm{mL}$ at activation temperature $90^{\circ} \mathrm{C}$, duration of activation 120 minutes, drying temperature $110^{\circ} \mathrm{C}$ and duration of drying 120 minutes with iodine number $634.50 \mathrm{mg} / \mathrm{g}$. The optimum mass of adsorbent is $1 \mathrm{~g}$ with percent of removal $69,19 \%$
\end{abstract}

Keywords : adsorbent, ngapi nut peel, wastewater, lead, iodine number

\section{Pendahuluan}

Kualitas dari air sangat penting untuk memenuhi kebutuhan dasar manusia dan lingkungan. Namun aktivitas industrial menyebabkan kualitas air menurun. Limbah yang berasal dari industri dapat mengandung kontaminan mikrobiologi, bahan kimia seperti pelarut organik dan anorganik, logam, nutrisi tanaman, bahan tersuspensi, perubahan temperatur dan sebagainya [14].

Limbah industri elektroplating berasal dari bahan-bahan kimia yang digunakan dan hasil dari proses pelapisan. Bahan-bahan kimia yang digunakan adalah beracun sehingga limbah yang dihasilkan berbahaya bagi kesehatan manusia.
Industri pelapisan logam umumnya mengandung krom $(\mathrm{Cr})$, tembaga $(\mathrm{Cu})$, seng $(\mathrm{Zn})$, nikel $(\mathrm{Ni})$, kadmium $(\mathrm{Cd})$ dan timbal $(\mathrm{Pb})$ karena logamlogam ini digunakan dalam proses produksi [21].

Logam berat dapat dipisahkan dari limbah cair dengan menggunakan berbagai metode seperti presipitasi, ekstraksi menggunakan pelarut, evaporasi vakum, teknologi membran, adsorpsi dan pertukaran ion [10]. Metode presipitasi dan pertukaran ion sangat sering digunakan untuk membersihkan air yang terkontaminasi dengan polutan logam. Namun metode ini tidak dapat mencapai standar baku 
mutu lingkungan yang direkomendasikan oleh Standar Badan Air Internasional [26].

Teknologi adsorpsi saat ini sedang digunakan secara ekstensif untuk menghilangkan logam berat dari larutan air karena merupakan teknologi yang lebih bersih, lebih efisien dan lebih murah [23]. Adsorben dapat dibuat dari berbagai limbah padat, diantaranya yaitu limbah kulit jengkol. Jengkol (Pithecellobium jiringa Prain) merupakan tanaman yang sudah sejak lama ditanam di Indonesia dan penggunaannya terbatas pada bijinya sebagai bahan makanan, sementara kulitnya dibuang sebagai sampah. Sejauh ini kulit jengkol baru dimanfaatkan sebagai bioherbisida dan biolarvasida [24]. Padahal kulit jengkol memiliki kandungan karbon yang tinggi yaitu sebesar 44,02\% [8] yang berpotensi untuk dimanfaatkan sebagai karbon aktif.

\section{Teori}

Tumbuhan jengkol atau lebih dikenal dengan tumbuhan Jering adalah termasuk dalam famili Fabaceae (suku biji-bijian). Tumbuhan ini memiliki nama latin Pithecellobium lobatum Benth. dengan nama sinonimnya yaitu A.Jiringa, Pithecellobium jiringa, dan Archindendron pauciflorum. Tumbuhan ini merupakan tumbuhan khas di wilayah Asia Tenggara [7]. Hasil penelitian menunjukkan bahwa tanaman jengkol banyak mengandung zat seperti protein, kalsium, fosfor, asam jengkolat, vitamin A dan B1, karbohidrat, minyak atsiri, saponin, alkaloid, terpenoid, steroid, tanin, dan glikosida [25].

Kulit Jengkol selama ini tergolong limbah organik yang berserakan di pasar tradisional dan tidak memberikan nilai ekonomis [25]. Menurut Gusnidar dkk. [8], kandungan hara kulit jengkol dapat dilihat pada Tabel 1.

\section{Tabel 1 Kandungan Hara Kulit Jengkol [8]}

\begin{tabular}{|c|c|}
\hline $\begin{array}{c}\text { Parameter } \\
\text { Pengamatan }\end{array}$ & Kadar (\%) \\
\hline Air & 65,56 \\
\hline N-total & 1,82 \\
\hline P-total & 0,32 \\
\hline K-total & 2,10 \\
\hline Ca-total & 0,27 \\
\hline Mg-total & 0,25 \\
\hline C-total & 44,02 \\
\hline
\end{tabular}

Meningkatnya kebutuhan akan produk hasil dari proses elektroplating menyebabkan perkembangan industri elektroplating yang berada di Indonesia semakin meningkat. Perkembangan industri tersebut memberikan manfaat, namun menimbulkan dampak negatif dari limbah yang dihasilkan. Limbah dari proses elektroplating merupakan limbah logam berat yang termasuk dalam limbah B3 [15].

Adsorpsi adalah salah satu dari proses pengolahan fisika kimia yang terbukti efektif dalam mengurangi logam berat dari limbah cair [26]. Adsorpsi merupakan metode yang efektif dan murah untuk mengolah limbah cair yang mengandung logam berat. Proses adsorpsi menawarkan fleksibilitas dalam desain dan operasinya pada berbagai kasus sehingga menghasilkan produk akhir yang memiliki kualitas baik [6]. Pada penelitian ini dilakukan proses adsorpsi menggunakan adsorben kulit jengkol untuk menyerap ion logam $\mathrm{Pb}$ (II) yang merupakan pengolahan tingkat ketiga dalam pengolahan limbah cair.

Karbon aktif merupakan adsorben yang paling sering digunakan dalam mengurangi kontaminan logam berat. Namun akhir-akhir ini ditemukan karbon aktif masih relatif mahal. Penelitian mengenai adsorben yang murah dan mudah diperoleh menjadi bahan pertimbangan saat ini [6].

Bilangan iodin merupakan parameter utama yang digunakan untuk melihat karakteristik dari adsorben maupun karbon aktif. Bilangan ini sering ditulis dengan satuan $\mathrm{mg} / \mathrm{g}$. Bilangan ini mengukur kandungan mikropori dengan cara menyerap iodin dari larutan [11].

Dalam menentukan kapasitas adsorpsi adsorben, bilangan iodin telah digunakan pada berbagai penelitian. Kemampuan adsorben dalam penyerapan senyawa iodin menunjukkan kemampuan adsorben tersebut untuk menyerap komponen dengan berat molekul yang rendah [20].

\section{Metodologi Penelitian \\ Alat dan Bahan}

Adapun bahan utama yang digunakan dalam penelitian ini adalah asam nitrat, limbah cair industri pelapisan logam dan kulit jengkol yang diperoleh dari pajak Simpang Limun, Medan. Larutan iodin, natrium tiosulfat, natrium hidroksida dan pati digunakan untuk keperluan analisa.

Alat yang digunakan dalam penelitian ini adalah ball mill, sieve tray, beaker glass, corong gelas, hot plate, magnetic stirrer, erlenmeyer, oven, labu ukur, $\mathrm{pH}$ meter, desikator, timbangan digital, buret, statif dan pipet tetes.

\section{Metode Penelitian \\ Prosedur Aktivasi Adsorben}

Kulit jengkol dicuci dengan air lalu dikeringkan di bawah sinar matahari selama 7 hari. Kulit Jengkol dihaluskan menggunakan 
ayakan berukuran 100 mesh. Kulit Jengkol diaktifkan dengan larutan asam nitrat $\left(\mathrm{HNO}_{3}\right) 4$ $\mathrm{N}$ dengan rasio kulit jengkol : asam nitrat 20:0,5 $\mathrm{mg} / \mathrm{mL} ; 20: 1 \mathrm{mg} / \mathrm{mL}$ dan $20: 1,5 \mathrm{mg} / \mathrm{mL}$ sambil dipanaskan selama 60 menit, 90 menit dan 120 menit pada suhu $70{ }^{\circ} \mathrm{C}, 80{ }^{\circ} \mathrm{C}$ dan $90^{\circ} \mathrm{C}$, lalu didinginkan. Setelah dingin, dilanjutkan dengan pencucian beberapa kali menggunakan aquadest untuk menghilangkan pengotor terlarut. Kemudian kulit jengkol dimasukkan ke dalam oven selama 60 menit, 90 menit dan 120 menit pada suhu $100{ }^{\circ} \mathrm{C}, 110^{\circ} \mathrm{C}$ dan $120^{\circ} \mathrm{C}$ [1].

\section{Prosedur Adsorpsi Batch}

Diukur $50 \mathrm{~mL}$ sampel limbah cair pelapisan logam dan dimasukkan ke dalam beaker glass. Diatur $\mathrm{pH}$ sebesar 5 dengan penambahan larutan $0,1 \mathrm{M} \mathrm{HNO}_{3}$ atau 0,1 M NaOH. Ditambahkan adsorben kulit jengkol yang melewati ayakan 100 mesh dengan massa $0,5 \mathrm{~g} ; 1 \mathrm{~g}$ dan $1,5 \mathrm{~g}$. Campuran diaduk menggunakan magnetic stirrer dengan kecepatan $30 \mathrm{rpm}$ dan dipertahankan selama 30 menit. Campuran disaring dengan corong gelas dan kertas saring Whatman No.1.

\section{Hasil dan Pembahasan}

\section{Bilangan Iodin Adsorben Kulit Jengkol}

Bilangan iodin adsorben sebelum aktivasi dihitung dan diperoleh nilainya sebesar 374,36 $\mathrm{mg} / \mathrm{g}$. Nilai ini sedikit lebih rendah daripada bilangan iodin adsorben biji asam jasa yaitu sebesar 379,81 mg/g seperti yang dilaporkan oleh peneliti sebelumnya [1]. Perbedaan hasil ini mungkin disebabkan karena perbedaan jumlah pengotor pada adsorben yang dihasilkan sebelum aktivasi dilakukan.

Pengaruh Suhu Aktivasi $\left({ }^{\circ} \mathrm{C}\right)$ dan Lama Aktivasi (menit) terhadap Bilangan Iodin Adsorben.

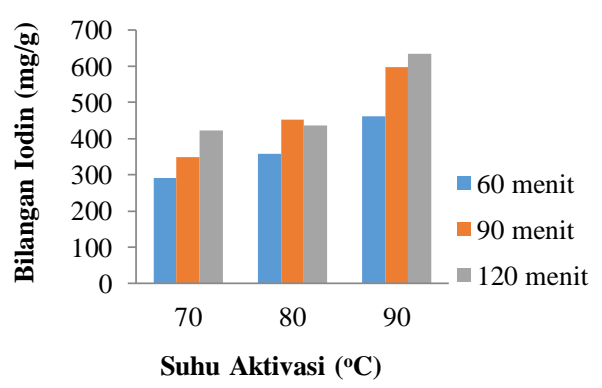

Gambar 1. Pengaruh Suhu dan Lama Aktivasi terhadap Bilangan Iodin Adsorben

Dari Gambar 1 dapat dilihat bahwa bilangan iodin cenderung meningkat seiring dengan semakin meningkatnya suhu aktivasi dan lama aktivasi. Bilangan iodin optimum diperoleh pada suhu aktivasi $90^{\circ} \mathrm{C}$ dan lama aktivasi 120 menit, yaitu $634,50 \mathrm{mg} / \mathrm{g}$.

Pada lama aktivasi 60 menit, 90 menit dan 120 menit bilangan iodin terus meningkat seiring bertambahnya suhu aktivasi. Hal ini menunjukkan semakin tinggi suhu aktivasi maka daya serap adsorben juga semakin meningkat. Pada suhu $70^{\circ} \mathrm{C}, 80^{\circ} \mathrm{C}$ dan $90^{\circ} \mathrm{C}$ bilangan iodin cenderung meningkat seiring dengan bertambahnya lama aktivasi. Hal ini menunjukkan bahwa semakin lama aktivasi, pori-pori adsorben semakin banyak terbuka sehingga meningkatkan daya serap adsorben.

Semakin meningkatnya suhu, pengotorpengotor yang menutup pori ikut terlepas sehingga memperluas permukaan adsorben. Hal ini juga mengakibatkan banyak komponen seperti air dan kandungan volatil keluar dari dalam adsorben. Besarnya permukaan adsorben yang terjadi ditandai dengan meningkatnya bilangan iodin [19]. Durasi aktivasi yang semakin lama dapat meningkatkan bilangan iodin suatu adsorben yang ditandai dengan meningkatnya kandungan karbon dalam adsorben tersebut [3].

Dengan membandingkan teori dan hasil yang diperoleh dari penelitian dapat disimpulkan bahwa kondisi optimum untuk menghasilkan adsorben dari kulit jengkol dengan bilangan iodin tertinggi adalah pada suhu aktivasi $90^{\circ} \mathrm{C}$ dan lama aktivasi 120 menit.

Pengaruh Suhu Pengeringan $\left({ }^{\circ} \mathrm{C}\right)$ dan Lama Pengeringan (menit) terhadap Bilangan Iodin Adsorben

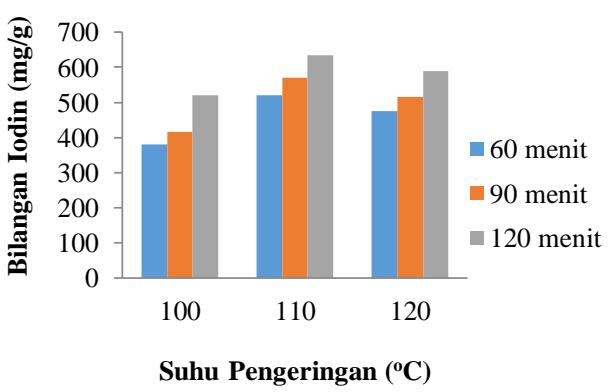

Gambar 2. Pengaruh Suhu dan Lama Pengeringan terhadap Bilangan Iodin Adsorben

Dari Gambar 2 di atas dapat dilihat bahwa bilangan iodin cenderung meningkat seiring dengan semakin meningkatnya suhu pengeringan dan lama pengeringan. Bilangan iodin paling besar diperoleh pada suhu pengeringan $110^{\circ} \mathrm{C}$ dan lama aktivasi 120 menit, yaitu 634,50 mg/g. 
Pada suhu 100 dan $110^{\circ} \mathrm{C}$ bilangan iodin meningkat, namun turun pada suhu $120^{\circ} \mathrm{C}$. Hal ini dapat terjadi karena beberapa kemungkinan. Pertama, kadar air sulit dikontrol sebelum dilakukan penyerapan iodin [1]. Kedua, ketidakmerataan adsorben dalam wadah saat proses aktivasi dilakukan sehingga assam nitrat tidak efektif dalam memodifikasi adsorben kulit jengkol.

Peningkatan suhu mengakibatkan banyak komponen seperti air dan kandungan volatil keluar dari dalam adsorben. Pengotor-pengotor pada bagian pori ikut terlepas pada suhu yang lebih tinggi sehingga memperluas permukaan adsorben [19]. Meningkatnya lama pengeringan dapat menyebabkan terbukanya mesopori dan mikropori yang dapat meningkatkan ukuran pori adsorben. [9]. Namun pada pemanasan yang berlebihan dapat terjadi pengurangan mesopori dan mikropori pada adsorben tersebut [19] serta menyebabkan kerusakan struktur dan dinding pori yang dapat menghambat pertumbuhan pori [2].

\section{Pengaruh Rasio Kulit Jengkol : Asam Nitrat (mg/mL) terhadap Bilangan Iodin Adsorben}

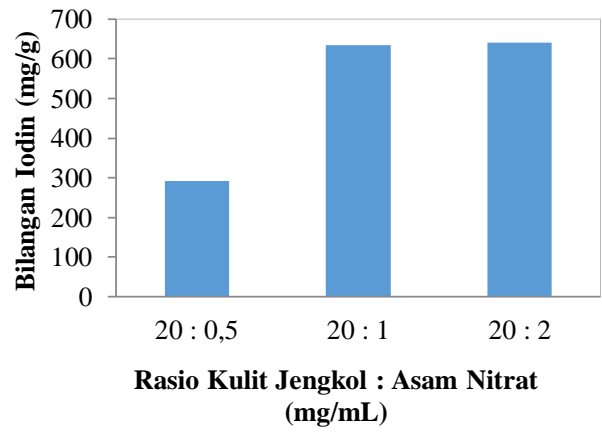

Gambar 3. Pengaruh Rasio Kulit Jengkol terhadap Bilangan Iodin Adsorben

Pada Gambar 3 di atas dapat dilihat bahwa bilangan iodin cenderung meningkat seiring dengan semakin tingginya rasio kulit jengkol : asam nitrat. Bilangan iodin paling besar diperoleh pada rasio 20:2.

Pada rasio 20:0,5; 20:1 dan 20:2 bilangan iodin terus meningkat. Meskipun demikian peningkatan bilangan iodin dari rasio 20:1 ke 20:2 sangat sedikit, sehingga dapat dianggap bahwa rasio 20:1 sudah cukup untuk memodifikasi adsorben dari kulit jengkol yang digunakan.

Semakin meningkatnya rasio bahan baku dengan aktivator maka daya serap adsorben akan meningkat. Hal ini disebabkan karena adanya dehidrasi kimia serta kondensasi yang semakin kuat sehingga menghasilkan struktur pori yang besar [22].

Dengan membandingkan teori dan hasil, dapat disimpulkan bahwa kondisi rasio kulit jengkol : asam nitrat yang paling optimum dalam menyerap senyawa iodin yaitu sebesar 20:1 dengan bilangan iodin $634,50 \mathrm{mg} / \mathrm{g}$.

Pengaruh Massa Adsorben (g) terhadap Kapasitas Adsorpsi Logam Pb (II)

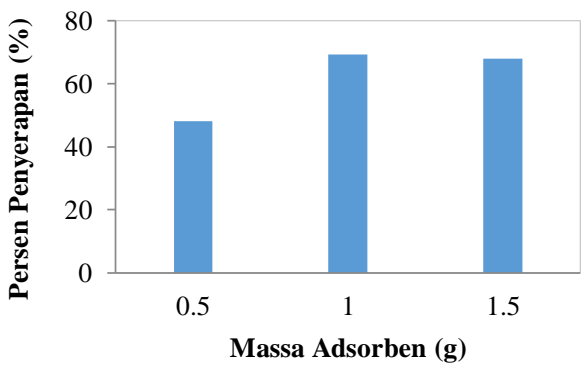

Gambar 4. Pengaruh Massa Adsorben terhadap Persen Penyerapan Ion $\mathbf{P b}$ (II)

Dari Gambar 4 di atas dapat dilihat bahwa persen penyerapan cenderung meningkat dengan semakin banyaknya massa adsorben yang digunakan. Persen penyerapan tertinggi diperoleh pada massa adsorben $1 \mathrm{~g}$ dengan persen penyerapan sebesar $69,19 \%$.

Pada massa adsorben 0,5 dan $1 \mathrm{~g}$ persen penyerapan terus meningkat. Namun pada massa adsorben 1,5 persen penyerapan mengalami penurunan. Hal ini dapat terjadi karena pada dosis tersebut adsorben membentuk gumpalangumpalan yang menyebabkan berkurangnya luas permukaan adsorben [24] dan perpindahan massa yang terjadi saat proses adsorpsi berlangsung menjadi kurang baik.

Semakin meningkatnya massa adsorben yang digunakan maka persentase penyerapan juga akan semakin meningkat. Hal ini disebabkan situs atau luas permukaan adsorpsi meningkat bersamaan dengan berat dari adsorben, sehingga memberikan hasil persen penghilangan logam yang lebih besar pada dosis adsorben yang lebih besar [18]. Persen penyerapan logam dapat berkurang dengan meningkatnya dosis adsorben dapat disebabkan oleh terbentuknya gumpalan yang menyebabkan menurunnya luas permukaan keseluruhan [12].

Dengan membandingkan teori dan hasil yang diperoleh dari penelitian, dapat disimpulkan bahwa massa yang paling optimum dalam menyerap logam $\mathrm{Pb}$ (II) yaitu sebesar $1 \mathrm{~g}$ yang dinyatakan dengan persen penyerapan sebesar $69,19 \%$. 
Karakteristik Gugus Fungsi pada Adsorben Kulit Jengkol dengan Spektrofotometri FTIR

Pada penelitian ini, adsorben sebelum diaktivasi, sesudah aktivasi dan sesudah menyerap logam berat $\mathrm{Pb}$ (II) dikarakterisasi gugus-gugus fungsinya menggunakan spektrofotometri FTIR. Setiap ikatan kimia yang spesifik menunjukkan pita absorpsi energi yang unik dalam analisa FTIR dan hal ini berguna untuk mengidentifikasi adanya gugus-gugus fungsional dari adsorbent [5]. Gugus-gugus fungsional yang terbentuk disimpulkan dengan membandingkannya dengan literatur yaitu tabel karakteristik pita IR berbagai senyawa [4] dan tabel frekuensi berbagai gugus-gugus fungsi [13]. Adapun hasil yang diperoleh dapat dilihat pada Gambar 5, 6 dan 7 berikut.

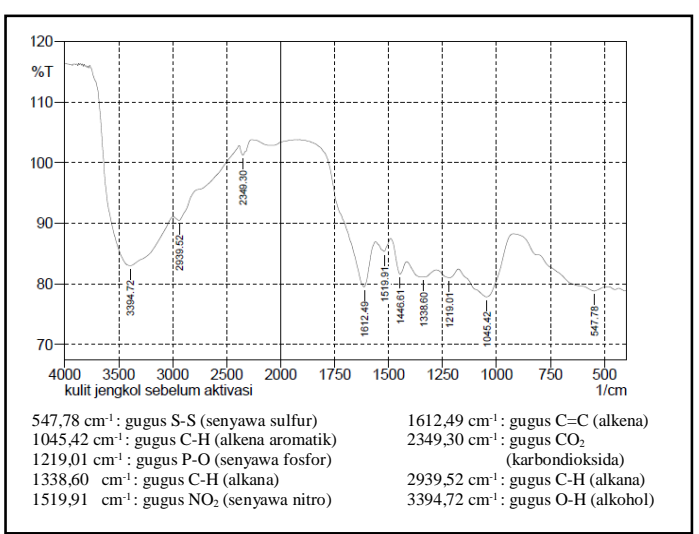

Gambar 5. Hasil Spektrofotometri FTIR Adsorben Kulit Jengkol Sebelum Aktivasi

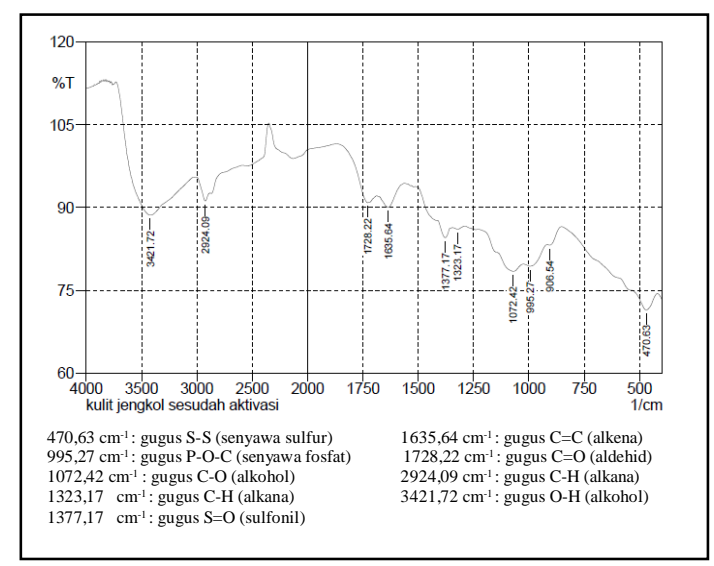

Gambar 6. Hasil Spektrofotometri FTIR Adsorben Kulit Jengkol Sesudah Aktivasi

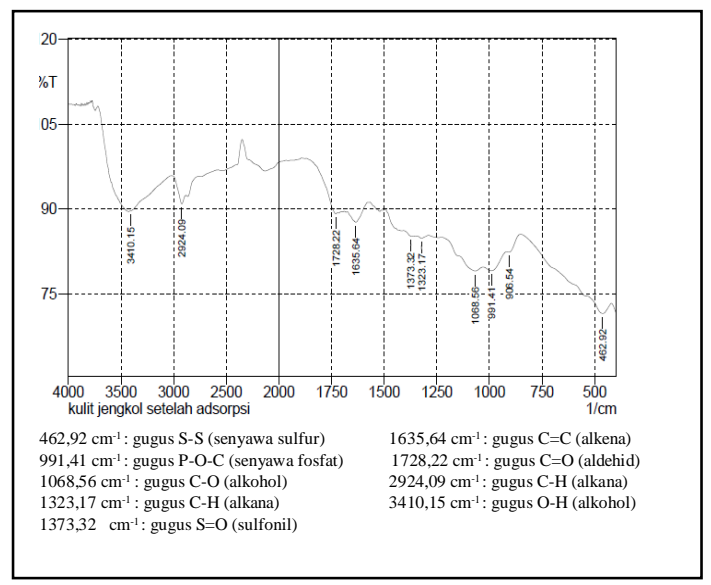

Gambar 7. Hasil Spektrofotometri FTIR Adsorben Kulit Jengkol Sesudah Adsorpsi

Dari Gambar 5, 6 dan 7 di atas dapat dibandingkan gugus-gugus fungsi yang terdapat pada adsorben sebelum dan sesudah aktivasi serta sesudah adsorpsi. Pada Gambar 5, yaitu adsorben sebelum aktivasi terlihat gugus fungsional hidroksil termasuk ikatan hidrogen (regangan $\mathrm{O}-\mathrm{H}$ ), yang semakin tidak tampak pada Gambar 6 dan 7 yaitu adsorben sesudah aktivasi dan sesudah adsorpsi. Reduksi dari ikatan hidrogen ini menunjukkan asam nitrat sebagai agen pengdehidrasi, bereaksi dengan bahan baku setelah kedua substansi tercampur. Pergeseran pita pada 2239,52 $\mathrm{cm}^{-1}$ sebelum diaktivasi menjadi 2924,09 $\mathrm{cm}^{-1}$ yang merupakan regangan $\mathrm{C}-\mathrm{H}$ juga menunjukkan adanya pelepasan sejumlah hidrogen secara signifikan. Pada adsorben sebelum diaktivasi terdapat regangan pada $1045,42 \mathrm{~cm}^{-1}$ yang merupakan regangan alkena aromatik $\mathrm{C}-\mathrm{H}$. Pita ini tidak terdapat pada adsorben sesudah aktivasi, sehingga dapat disimpulkan aktivasi kimia melepaskan banyak ikatan pada senyawa aromatik dan mengeliminasi banyak substratsubstrat ringan dan volatil [17].

Dari Gambar 6 dan 7 dapat dilihat perbedaan antara adsorben sebelum dan sesudah adsorpsi tidak mengubah struktur kerangka dari adsorben kulit jengkol. Namun terjadi pergeseran pita yaitu dari 3421,72 menjadi 3410,15 $\mathrm{cm}^{-1}$ menunjukkan adanya pengikatan logam timbal pada gugus hidroksil. Juga terjadi pergeseran pita pada 1377,17 menjadi $1373,32 \mathrm{~cm}^{-1}$ yaitu regangan gugus sulfonil $\mathrm{S}=\mathrm{O}$ yang juga semakin berkurang ketajamannya pada adsorben setelah adsorpsi. Hal ini menunjukkan gugus sulfonil terlibat dalam proses adsorpsi logam seperti yang dilaporkan oleh peneliti sebelumnya [16].

. Perubahan yang lain juga dapat dilihat yaitu dari 995,27 menjadi $991,41 \mathrm{~cm}^{-1}$ untuk regangan senyawa fosfat P-O-C serta dari 470,63 menjadi 
$462,92 \mathrm{~cm}^{-1}$ untuk regangan senyawa merkaptan $\mathrm{S}-\mathrm{S}$, yang menunjukkan bahwa senyawa tersebut juga terlibat selama proses adsorpsi logam timbal. Pergeseran pita yang ditunjukkan oleh spektrum FTIR ini menunjukkan bahwa gugus hidroksil, sulfonil, fosfor dan merkaptan terlibat selama proses adsorpsi logam timbal.

\section{Kesimpulan}

Adapun kesimpulan yang dapat diambil dari penelitian ini adalah:

1. Bilangan iodin adsorben paling besar adalah $634,50 \mathrm{mg} / \mathrm{g}$ yang diperoleh pada aktivasi dengan suhu $90^{\circ} \mathrm{C}$ selama 120 menit dan pada pengeringan dengan suhu $110^{\circ} \mathrm{C}$ selama 120 menit serta rasio kulit jengkol : asam nitrat 20:1 mg/mL.

2. Adsorpsi terbaik terhadap ion logam $\mathrm{Pb}$ (II) diperoleh pada massa adsorben $1 \mathrm{~g}$ dengan persen penyerapan sebesar $69,19 \%$.

3. Aktivasi kimia pada adsorben dapat mereduksi ikatan hidrogen, melepas senyawa aromatik dan mengeliminasi berbagai substrat yang ringan dan volatil serta pada prosesnya, adsorpsi logam $\mathrm{Pb}$ (II) melibatkan gugus hidroksil, sulfonil, fosfor dan merkaptan.

\section{Daftar Pustaka}

[1] Agus Mangiring Siburian, Agnes Sartika Doharma Pardede, Setiaty Pandia, Pemanfaatan Adsorben dari Biji Asam Jawa untuk Menurunkan Bilangan Peroksida pada CPO (Crude Palm Oil), Jurnal Teknik Kimia USU, 3(4) 2014 : hal. 12 - 14.

[2] Allwar, Ahmad Bin Md Noor, Mohd Asri Bin Mohd Nawi, Textural Characteristics of Activated Carbons Prepared from Oil Palm Shells Activated with $\mathrm{ZnCl}_{2}$ and Pyrolysis Under Nitrogen and Carbon Dioxide, Journal of Physical Science, 19(2) 2008 : hal. 93 - 100.

[3] Amalia Aisha Noer, Awitdrus, Usman Malik, Pembuatan Karbon Aktif dari Pelepah Kelapa Sawit Menggunakan Aktivator $\mathrm{H}_{2} \mathrm{O}$ Sebagai Adsorben, JOM FMIPA, 1(2) 2014 : hal. 42 - 46.

[4] Barbara Stuart, Infrared Spectroscopy: Fundamentals and Applications (John Wiley \& Sons Ltd,1999), hal. 71 - 86.

[5] Bindra Shrestha, Jagjit Kour, Puspa Lal Homagai, Megh Raj Pokhrel, Kedar Nath Ghimire, Surface Modification of The Biowaste for Purification of Wastewater Contaminated with Toxic Heavy MetalsLead and Cadmium, Advances in Chemical Engineering and Science, III 2013, hal. 178 $-180$.
[6] Fenglian Fu, Qi Wang, Removal of Heavy Metal Ions from Wastewaters: A Review, Journal of Environmental Management, 92 (Desember 2010), hal. 407 - 414.

[7] Frisca Febe Lumban Gaol, Pengaruh Pemberian Ekstrak Etanol Biji Jengkol (Pithecellobium lobatum Benth.) Terhadap Penurunan Kadar Glukosa Darah dan Peningkatan Kadar Ureum dan Kreatinin Tikus Putih (Rattus norvegicus) Jantan Galur Sprague Dawley yang Diinduksi Aloksan, Skripsi, Program Studi Pendidikan Dokter Universitas Lampung, Bandar Lampung, 2014, hal 8 - 11.

[8] Gusnidar, Yulnafatmawita, Rosa Nofianti, Pengaruh Kompos Asal Kulit Jengkol (Phitecolobium jiringa Jack Prain ex King) Terhadap Ciri Kimia Tanah Sawah dan Produksi Tanaman Padi, J. Solum, VIII (Juli 2011), hal 58 - 60.

[9] Hayan Mao, Dingguo Zhou, Zaher Hashisho, Sunguo Wang, Heng Chen, Haiyan (Helena) Wang, Preparation of Pinewood and Wheat Straw-Based Activated Carbon Via A MicrowaveAssisted Potassium Hydroxide Treatment and An Analysis of The Effects of The Microwave Activation Conditions, Bioresources, 10(1) 2015 : hal 809 - 817.

[10] Horea Bedelean, Andrada Maicaneanu, Maria Stanca, Silvia Burca, Removal of Heavy Metal Ions from Wastewaters Using Natural Materials, MAEGS, XVI (2009) : 179.

[11] Itodo A. U., Abdulrahman F. W., Hassan L. G., Maigandi S.A., Itodo H.U., Application of Methylene Blue and Iodine Adsorption in the Measurement of Specific Surface Area by Four Acid and Salt Treated Activated Carbons, New York Science Journal, 3(5) 2010 : hal. 25 - 26.

[12] Jamal A. Abudaia, Muhamed O. Sulyman, Khalad Y. Elazaby, Salah M. Ben-Ali, Adsorption of $\mathrm{Pb}$ (II) dan $\mathrm{Cu}$ (II) from Aqueous Solution onto Activated Carbon Prepared from Dates Stones, International Journal of Environmental Science and Development, 4(2) 2013, hal. 191 - 194.

[13] John Coates, Interpretation of Infrared Spectra, A Practical Approach (John Wiley \& Sons Ltd, 2000), hal. 1 - 15.

[14] Meena Palaniappan, Peter H. Gleick, Lucy Allen, Michael J. Cohen, Juliet ChristianSmith, Courtney Smith, Clearing the Waters, Pasific Institute, Oakland, 2010, hal 12 - 13.

[15] Nurhasni, Zainus Salimin, Ita Nurifitriyani, Pengolahan Limbah Industri Elektroplating 
dengan Proses Koagulasi Flokulasi, Valensi, 3(1) 2013 : hal. 41

[16] Putri Isnaini, Rahmiana Zein, Edison Munaf, Penyerapan Ion Cd (II) dan Zn (II) dalam Air Limbah Menggunakan Kulit Jengkol (Pithecellobium jiringa Prain.), Jurnal Kimia Unand, 2(3) $2013: 1$ - 2.

[17] Roozbeh Hoseinzadeh Hesas, Arash AramiNiya, Wan Mohd Ashri Wan Daud, J.N. Sahu, Preparation and Characterization of Activated Carbon from Apple Waste by Microwave-Assisted Phosporic Acid Activation: Application in Methylene Blue Adsorption, Bioresources, 8(2) 2013, hal. 2950 - 2966.

[18] Sarifah Fauziah Syed Draman, Norzila Mohd, Nor Hafiza Izzati Wahab, Nurul Syahirah Zulkfli, Nor Fatin Adila Abu Bakar, Adsorption of Lead (II) Ions In Aqueous Solution Using Selected AgroWaste, ARPN Journal of Engineering and Applied Sciences, 10(1) 2015, hal. 297 299.

[19] Siti Jamilatun, Martomo Setyawan, Pembuatan Arang Aktif dari Tempurung Kelapa dan Aplikasinya untuk Penjernihan Asap Cair, Spektrum Industri, 12(1) 2014 : hal. 78 - 79.

[20] Siti Tias Miranti, Pembuatan Karbon Aktif dari Bambu dengan Metode Aktivasi Terkontrol Menggunakan Activating Agent $\mathrm{H}_{3} \mathrm{PO}_{4}$ dan $\mathrm{KOH}$, Skripsi, Departemen Teknik Kimia Universitas Indonesia, Depok, 2012, hal 5 - 26.

[21] Sukmawati, Penggunaan Kitosan Manik Sebagai Adsorben Untuk Menurunkan Kadar $\mathrm{Pb}$ (II) dan Cr (II) dalam Limbah Cair Industri Pelapisan Logam, Tesis, Program Magister Teknik Kimia USU, Medan, 2006, hal. 15.

[22] Suqin Li, Liingling Zhang, Baiyi Pan, Guohong Xiong, Daqiang Cang, Study on Preparation and Charaterization of The Adsorbents With Sewage Sludge, Srcosmos, 2010, hal. 1 - 3.

[23] U. Adie Gilbert, I. Unuabonah Emmanuel, A. Adeyemo Adebanjo, G. Adeyemi Olalere, Biosorptive Removal of $\mathrm{Pb} 2+$ and Cd 2+ onto Novel Biosorbent Defatted Carica Papaya Seeds, Biomass and Bioenergy, XXV (2011) : 2517.

[24] Uzami Hamzah, Rahmiana Zein, Edison Munaf, Kulit Jengkol (Pithecellobium jiringa Prain.) Sebagai Biosorben Untuk Penyerapan Ion Logam $\mathrm{Pb}$ (II) dan $\mathrm{Cu}$ (II) dari Air Limbah Jurnal Kimia Unand, 2(2) 2013 : hal. 1 - 2.
[25] Vindi Wiasih, Anggi Permana, Nova Silvyani, Pramita Naily Faizah, Pemanfaatan "Uje" (Kulit Jengkol) Sebagai Larvasida Alami Pada Nyamuk Aedes Aegypti, Penelitian, Program Kreativitas Mahasiswa Universitas Dian Nuswantoro, Semarang, 2013, hal 3.

[26] Yahya S. Al-Degs, Musa I. El Barghouthi, Ayman A. Issa, Majeda A. Khraisheh, Gavin M. Walker, Sorption of Zn (II), Pb (II), and Co (II) using natural sorbents: Equilibrium and Kinetic Studies, Water Research, 40 (Mei, 2006), hal 2645. 